\title{
ORGANISATIONAL ARRANGEMENTS AND DRINKING WATER QUALITY
}

\author{
J. O. Jenkins
}

School of Life Sciences, University of Hertfordshire, College Lane, Hatfield, Hertfordshire, AL10 9AB, UK (E-mail: j.o.jenkins@herts.ac.uk)

\begin{abstract}
This paper discusses the findings of a research project which explored the impact of varying organisational arrangements on drinking water quality in England and Wales, and the Republic of Ireland. It is established that drinking water quality has been of a consistently higher standard in England and Wales in comparison with the Republic of Ireland. It is also demonstrated that the associated organisational arrangements in England and Wales have been more successful in tackling certain problematic drinking water quality parameters. The paper concludes by arguing that national governments, and their regulatory agencies, should view the rationalisation of organisations involved in the provision of drinking water as key to ensuring better drinking water quality. It is also suggested that state regulators who are responsible for ensuring the quality of drinking water end their dependency on water providers for quality data. They should instead become capable of directly monitoring drinking water quality via their own sampling regime. It is argued that this organisational arrangement would be representative of a more progressive and robust organisational approach to ensuring the supply of safe high quality drinking water.
\end{abstract}

\section{Keywords}

Organisational arrangements; policy transposition; drinking water quality; Directive 80/778/EEC; England/Wales; and Ireland

\section{INTRODUCTION}

This paper establishes the quality of drinking water in England and Wales and the Republic of Ireland ${ }^{1}$, and the organisational arrangements associated with it, for the period 1970 to 2002. The standards laid down by the Drinking Water Directive 80/778/EEC are used to provide the analytical backdrop for evaluating the quality of drinking water. The quality of drinking water in England/Wales is shown to have been of a consistently higher standard than in comparison with Ireland, which is subsequently revealed as having developed less effective organisational arrangements for the delivery and regulation of drinking water quality. The paper also establishes the organisational provision of drinking water in England/Wales and Ireland to diverge in three broad areas; namely, with regard to the role of government in provision; the role of government in finance; and the role of government in regulation.

To explore the quality of drinking water and the associated organisational arrangements in England/Wales and Ireland, this paper has been split into four main sections. The first section provides an overview of the methodology, the second

\footnotetext{
${ }^{1}$ To aid conciseness from this point onwards, England and Wales are referred to as England/Wales, and the Republic of Ireland is referred to as Ireland.
} 
establishes the quality of drinking water in England/Wales and Ireland; the third details the associated organisational arrangements. The paper is then drawn to close with a discussion and conclusions section.

\section{METHODOLOGICAL OVERVIEW}

To allow an investigation into the quality of drinking water and the associated organisational arrangements, and their impacts to take place, data was collected from reports and papers from parliamentary committees and proceedings, government departments, EU organisations and institutions, privately commissioned research, interviewee articles and conference presentations. The Times and Irish Times were also consulted to aid in the construction of a contemporary picture of the organisational set-up. The quality of drinking water was ascertained from analysis of published annual reports on the quality of drinking water. Interviewees were selected to represent the organisations and individuals associated with the supply and regulation of drinking water. Directive 80/778/EEC was used to guide the timeframe of this project, because of the central and fundamental role it has played in drinking water regulation in the European Union (Breach, 1989; CEC, 1980; Collins, 1988; Kramer, 2000; NSCA, 2000; Semple, 1993).

In Ireland, a total of 19 interviews were undertaken with individuals from the Department of the Environment and Local Government (DOELG), the Environmental Protection Agency (EPA). Individuals from the providers of water services were also selected for interview, which included Dublin City Council, Fingal County Council, Rathdown County Council, and South Dublin City Council. In England/Wales, a total of 33 interviews were undertaken with individuals from the Department for Environment Food and Rural Affairs, the Office of Water Services (Ofwat), the Drinking Water Inspectorate (DWI), and WaterVoice. Representatives of the providers of water services in the London area, namely Thames Water and Three Valleys Water, in addition to individuals from national representative groups such as Water UK, were also selected for interview. At the EU level a total of 12 individuals were interviewed, being drawn from the EC and the European Parliament (EP). Individuals were also selected for interview from the European Union of National Associations of Water Suppliers and Waste Water Services (EUREAU).

The rationale for selecting individuals representative of the above organisations was fourfold. Firstly, officials from the Environment Commission were selected as representatives of the EU Commission with responsibility for water policy. The senior officials selected were in a good position to explain the organisational arrangements of Member States within the context of Directive 80/778/EEC (CEC, 1992; Weale et al., 2000). Secondly, senior representatives from relevant sections of the civil service in England/Wales and Ireland were selected to provide information on the organisational provision and regulation of drinking water in each country. Within each country, interviewees were selected to represent all the geographical tiers of government that are involved in supply and regulation of drinking water (CEC, 1992; OECD, 1994, 2000; Weale et al., 2000). Thirdly, representatives of water providers were chosen to provide information from the perspective of those with a day-to-day responsibility for drinking water. Information from such interviews was intended to cross-check views on the organisational arraignments put in place by national governments. Fourthly, interviews were conducted with senior representatives of 
water providers in order to gain an overview of transposition and practical application responses from a wider national and supranational perspective.

Individuals for interview were identified from articles in professional publications, in related academic research literature, and through direct liaison with individuals responsible for the regulation and delivery of drinking water. This 'multiple entry' approach was adopted for three key reasons: prevention of bias, minimising the chances of capture by an interview network, and to minimise the impact of disruptive, un-cooperative or unsuitable interviewees (Rubin and Rubin, 1995). A snowballing technique was employed when representatives of each key actor grouping were approached for the first time, so allowing an interview network to be constructed that was independent of previous research, while also enabling the researcher to seek new information and perspectives on organisational arrangements (Mason, 1998, Arksey and Knight, 1999, Patton, 2002).

A numeric limit to sample size was not set at the beginning of the research. Instead interviews in England/Wales were curtailed when it was felt that new interviewees were not contributing new information and that regularities in accounts of processes/events had emerged (Guba, 1978). While this situation may lead to concerns associated with the reliability and robustness of findings when the sample size is small, this is a well tried and tested approach to research that is capable of pursuit with rigour (Minichiello et al., 1995, Baxter and Eyles, 1997; Patton, 2002). In regard to what is commonly known as 'network closure', Rubin and Rubin (1995: 72) make the following comment; 'you keep adding interviewees until you understand [...] When each additional interviewee adds little to what you have already learned, you stop adding new interviewees'.

By targeting the aforementioned interviewees different perspectives on organisational arrangements and outcomes were collated. This method of information collection, known as 'triangulation', as well as referring to using different sorts of data, enabled the trustworthiness and credibility of research findings to be enhanced. Triangulation facilitated insights that cast different views, so exposing inconsistencies and posing new questions that required reconciliation in order for understanding to be advanced (Lincoln and Guba, 1985; Denzin, 1989; Flick, 2002). The triangulation of information was enhanced further by deriving data on the key themes in interviews from papers from Parliamentary committees and proceedings, reports from government departments, EU organisations and institutions, privately commissioned research, interviewee journal research articles and conference presentations. In addition to these sources of information, the Times and Independent newspapers in England/Wales, and the Irish Times in Ireland, were consulted for relevant articles on the Drinking Water Directive. By drawing upon such secondary sources of information, the process of data triangulation was extended. This process allowed the trustworthiness and credibility of the research findings to be further tested (Hoggart et al., 2002; Patton, 2002). Such sourcing of information further allowed information obtained from individuals to be confirmed and gaps in individual responses to be explored (Jick, 1983; Denzin, 1989; Arksey and Knight, 1999). However, there are concerns surrounding triangulation. In particular, Blaikie (1991) and Mason (1998) argue that one should take care when utilising information from different sources because such information can be based upon assumptions about differing issues rather than differing aspects of the same phenomena. 
That said, where the research undertaken transcends a number of decades (as with this research), the memories of individuals whom it may be pertinent to interview may have become distorted and/or have become incomplete. For example, Roy Jenkins comments:

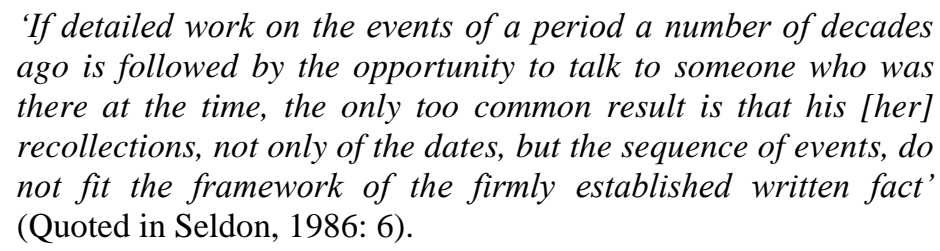

Therefore, referral to secondary information helped clarify insights and lessen the prospect of inadequate recall leading to a questioning of the dependability of research findings (Lincoln and Guba, 1985; Seldon, 1986). Secondary information also enables the intrinsic bias that comes from single-methods, single-observer, and single-theory studies' (Denzin, 1989: 307) to be overcome. In addition, Hodder (2000) suggests that written texts are useful in providing historical information that would not otherwise be forthcoming in spoken form.

\section{DRINKING WATER QUALITY AND THE DIRECTIVE}

To ascertain the quality of drinking water the following analysis has been split into two main sections. The first section focuses on water quality in England/Wales and Ireland during the 1970s and 1980s. The second section focuses on the quality of drinking water in England/Wales and Ireland between 1990 and 2002. This split represents the two periods before and after data on drinking water quality were coordinated and published nationally on an annual basis.

\section{Drinking water quality in England/Wales and Ireland 1970 to 1989}

From 1970 to 1989 , Ireland is notable for lacking nationally collated data on drinking water quality and exhibiting little public or media commentary on the quality of drinking water. This lack of data was commented on three years after Ireland was supposed to be compliant with standards in Directive 80/778/EEC. Hence, in 1988, an administrative circular issued by the Irish DOELG remarked that:

\footnotetext{
'The Department has relatively little information on the monitoring of toxic parameters [...] insofar as drinking water is concerned' (Circular L8/88 DOELG [Ireland]: 1).
}

Concern over contamination of surface and groundwater by organic and inorganic substances, like nitrate and pesticides, began to emerge in Ireland during the 1970s. Yet contamination was not believed to affect the quality of drinking water adversely (see Flanagan and Toner, 1972; IIRS, 1975; O'Donnell, 1980; Toner and Lennox, 1980; Daly and Daly, 1984; Water Resources Division, 1986). A lack of commentary on drinking water quality in the debates of the Dáil Eireann (i.e. Parliament in Republic of Ireland) provides further confirmation of low levels of concern amongst Members of Parliament during the 1970s and 1980s. Where concern was identified, its appears to have been limited to one-off phenol contamination in North Dublin, which was not taken to be indicative of wider quality problems (see DE Debs., Vol. 346, 22-11-83). Only toward the end of the 1980s did direct questions and data relating to the quality of drinking water begin to emerge, in particular with regard to 
the level of nitrate contained in ground water (see DE Debs., Vol. 392, 02-11-89). It appears that during the 1970s and 1980 drinking water quality in Ireland was of little concern, or was perceived not be a concern. In a sense there are parallels here between Ireland and England/Wales, for in the latter the debate surrounding the quality of drinking water similarly focused on contamination by one or two substances. Thus, in the 1970s and 1980s, an emerging concern about contamination by lead and nitrate was identified (Pearce, 1982).

In 1976, a UK survey on lead in drinking water revealed contamination to be far more widespread than previously thought (DoE, 1977; Atkinson, 1978). The report highlighted that while lead rarely occurs as a widespread natural contaminant, it tends to be present in drinking water due to the plumbosolvency of drinking water supplies (Nicolson, 1993). Prior to this survey, it was believed that only soft water dissolved lead from water pipes made from the metal. As a result of taking 2,600 samples, it was revealed that both soft and hard water had a plumbosolvency effect, and that the contamination of drinking water was more widespread that previously thought. During the course of the 1970s, concern also began to be attached to the level of nitrate in drinking water. In particular, nitrate contamination became of increased concern following the 1976 drought. This caused a sharp increase in concentrations in surface waters, with rising nitrate levels detected in groundwater in years following the drought. This caused suppliers of drinking water to consider other sources of groundwater supply (Atkinson, 1978). A further indicator of variable water quality was a 1984 government reply to a parliamentary enquiry on the number of suppliers breaching microbiological standards in Directive 80/778/EEC. It was reported that 90 water supply areas, out of an unspecified number, were falling 'marginally short of the EC drinking water directive's microbiological standards at present' (HC Debs., Vol. 84, 21-1-85, Col 551). The above information appears to indicate that problems relating to drinking water quality were isolated to a series of specific parameters and sources. However, the reported 1982 comments of Dr John Cuthbert, the then Director of the Water Research Centre's Stevenage process engineering laboratories, appears to indicate a more dire picture. He reported to the National Water Council and to Government ministers that 50 per cent of all British water supplies failed to meet some part of the Directive (Pearce, 1982: 114).

\section{Drinking water quality in England/Wales and Ireland 1990 to 2002}

This section presents the results of a comparative analysis of drinking water quality in England/Wales and Ireland for the period 1990 to 2002. It draws upon publicly available reports on drinking water quality. The starting point of 1990 represents the year data first become available in both national contexts. The end point of 2002 is the end point for data analysis as it represents the end of the data collection phase for this study. Overall compliance levels and levels for the individual standards relating to lead, nitrate, total coliforms, aluminium, iron, and pesticides are examined. As Figure 1 illustrates, the overall quality drinking water quality is higher in England/Wales than in Ireland.

Between 1990 and 2002, the percentage compliance ratings for drinking water quality in England/Wales and Ireland improved, with England/Wales exhibiting a consistently higher overall compliance. As Figure 1 demonstrates, the overall compliance in England/Wales increased from $98.82 \%$ to $99.85 \%$ (an increase of $1.03 \%$ ). While in Ireland it increased from $93.21 \%$ to $95.90 \%$ (an increase of $2.69 \%$ ). 
In both cases, the overall improvement was relatively small in percentage terms, yet overall compliance masks important and dramatic improvements in non-compliance failures for certain parameters.

Figures 2 through 5 illustrate a pronounced rise in the percentage of tests in England/Wales meeting the Directive's prescribed standards for nitrate, total coliforms, aluminium and iron. In particular, between 1990 to 2002, the percentage of tests not meeting the standard for nitrate fell from $0.77 \%$ to $0.11 \%$ (see Figure 2); for total coliforms it fell from $2.00 \%$ to $0.52 \%$ (see Figure 3); for aluminium from $0.90 \%$ to $0.07 \%$ (see Figure 4); and for iron from $3.00 \%$ to $0.83 \%$ (Figure 5). 
Figure 1. Drinking water quality in England/Wales and Ireland between 1990 and $2002^{2,3,4}$

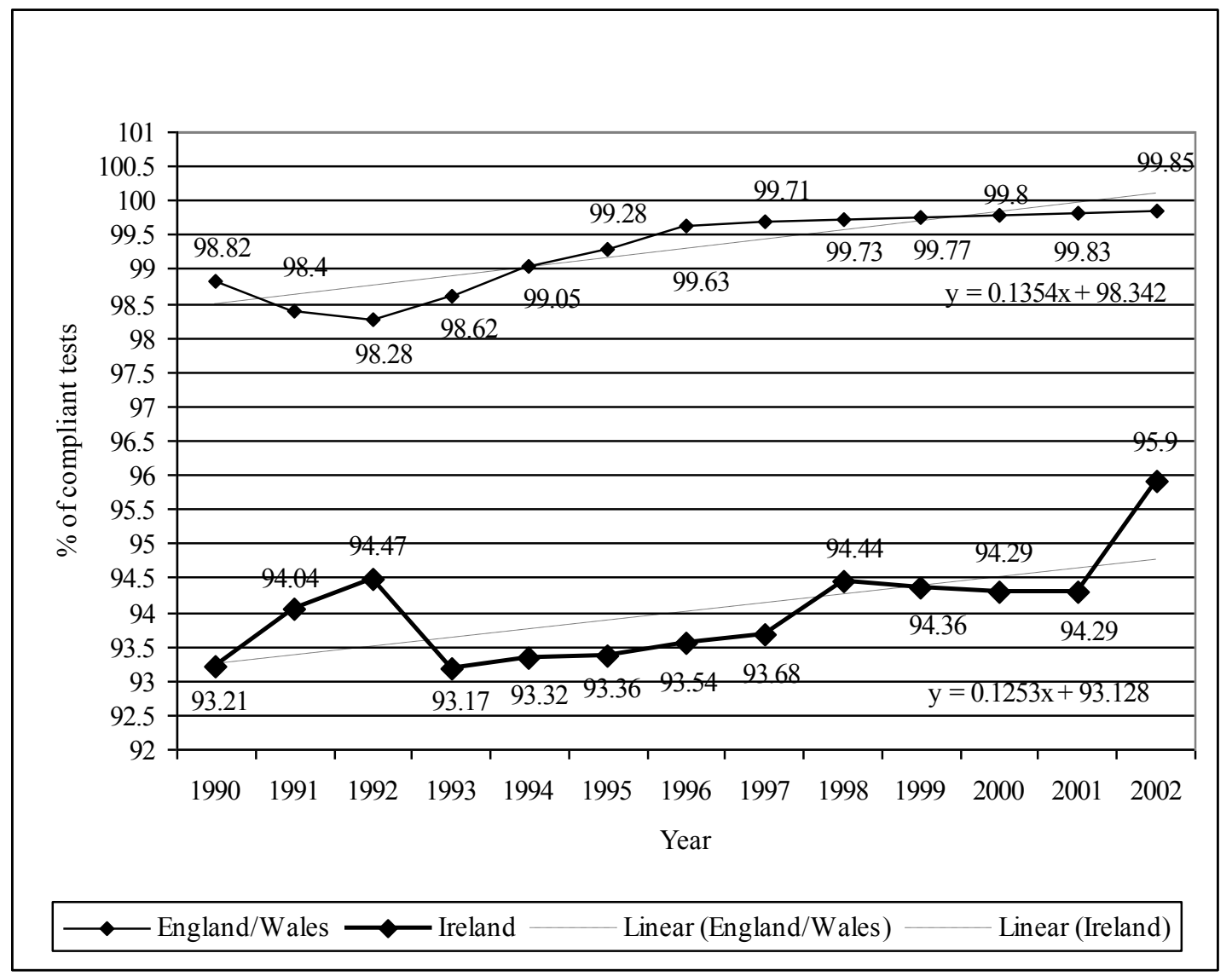

(Source: DWI, 1991-2003; EPA, 1991-2003)

\footnotetext{
${ }^{2}$ The percentage rating for overall compliance was calculated in relation to parameters reported in annual reports. In the case of England/Wales, the parameters reported include: total coliforms; faecal coliforms; colour; turbidity; odour; taste; hydrogen ion; nitrate; nitrite; aluminium; iron; manganese; lead; PAH (polycyclic aromatic hydrocarbons); trihalomethanes; total pesticides (all pesticide sampled for); individual pesticides (e.g. simazine; atrazine; propyzamide); all others (refers to 38 other parameters regularly tested for but rarely found at non-compliant levels [e.g. copper; zinc; temperature]). In relation to Ireland, the parameters reported upon include: aluminium; ammonium; total and faecal coliforms; colour; fluoride; heavy metals (e.g. copper, zinc, cadmium; lead); iron; manganese; nitrate; nitrite; odour; taste; $\mathrm{pH}$; trihalomethanes; turbidity; cryptosporidium (EPA, 2003).

${ }^{3}$ It is acknowledged that use of a linear trend line is not ideal for 13 observations. The line has only been used to highlight the overall trend in the data presented.

${ }^{4}$ In 2002 the EPA decided to discontinue calculating an overall compliance rating for drinking water quality in relation to the parameters detailed in footnote 10 (EPA, 2003). Discussion by the EPA of parameters would either make sole reference to the overall percentage compliance rating for a parameter, or break it down with regard to group and public water schemes. No data were then provided on the number of samples passed or failed in group and/or public water schemes. As a consequence, it is not possible to calculate overall compliance because the number of samples analysed in group and public water schemes is not known.
} 
Figure 2. Drinking water quality in England/Wales and Ireland in relation to nitrates, 1990-2002

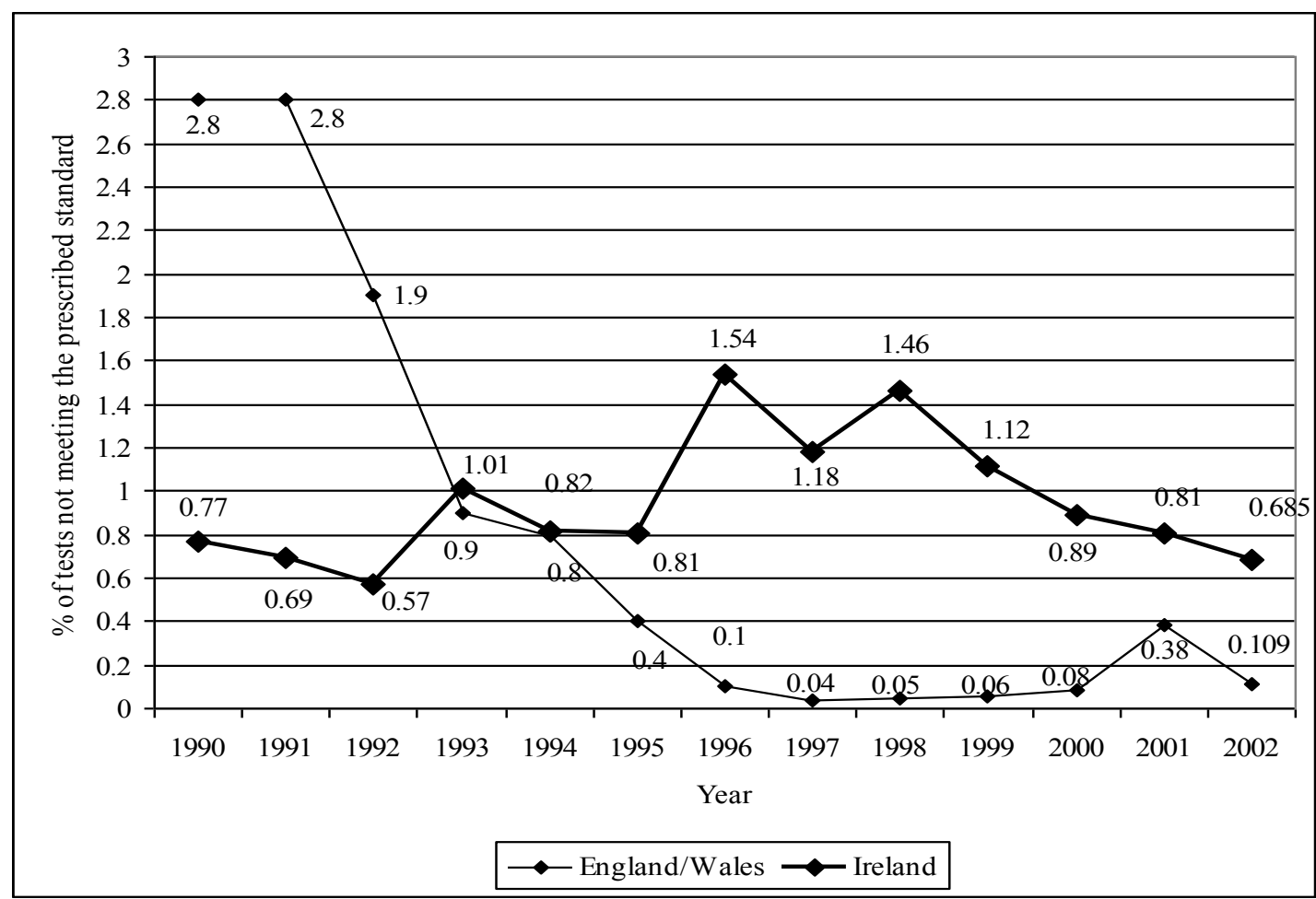

(Source: DWI, 1991-2003; EPA, 1991-2003)

Figure 3. Drinking water quality in England/Wales and Ireland in relation to total coliforms, 1990-2002

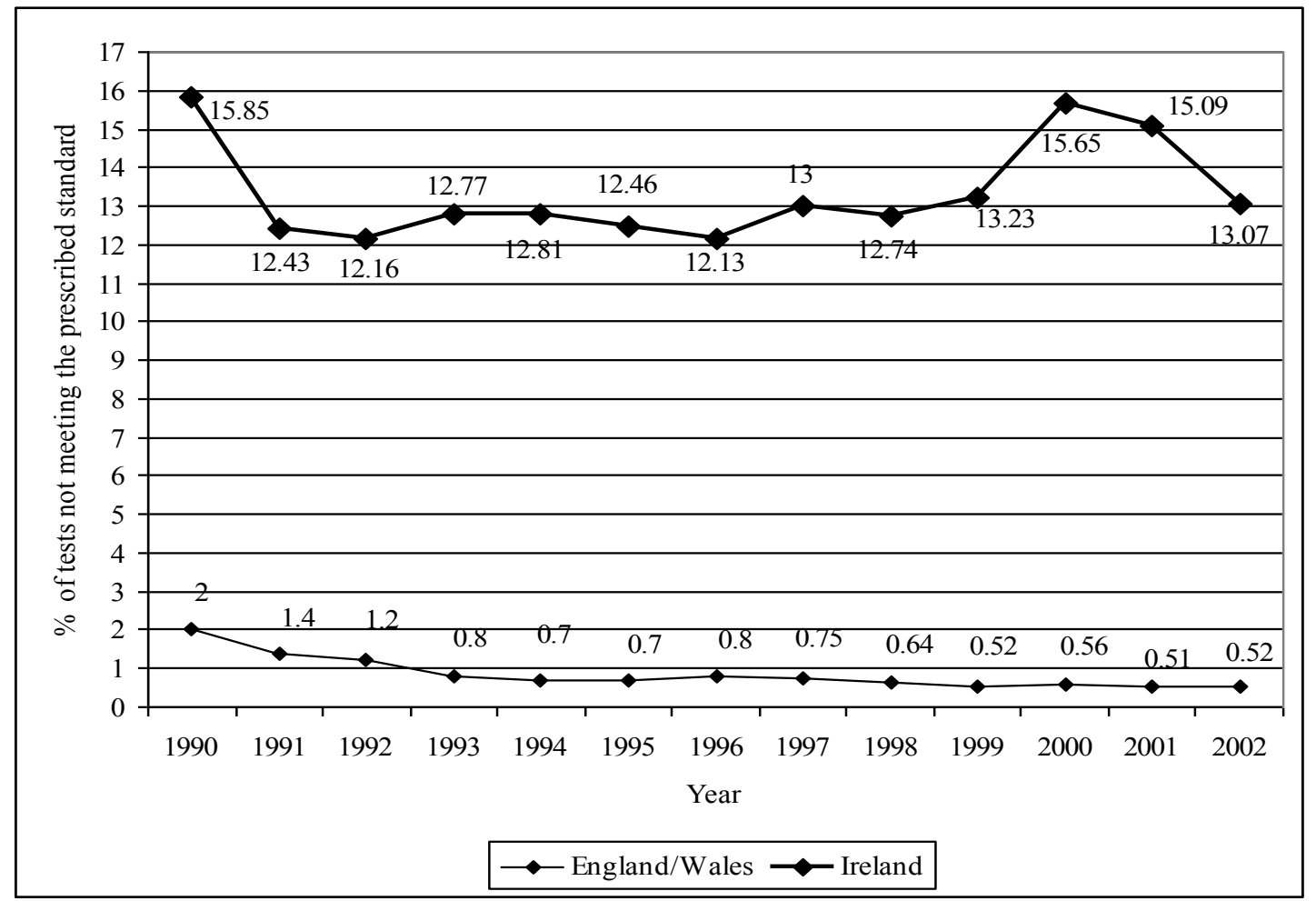

(Source: DWI, 1991-2003; EPA, 1991-2003) 
Figure 4. Drinking water quality in England/Wales and Ireland in relation to aluminium, 1990-2002

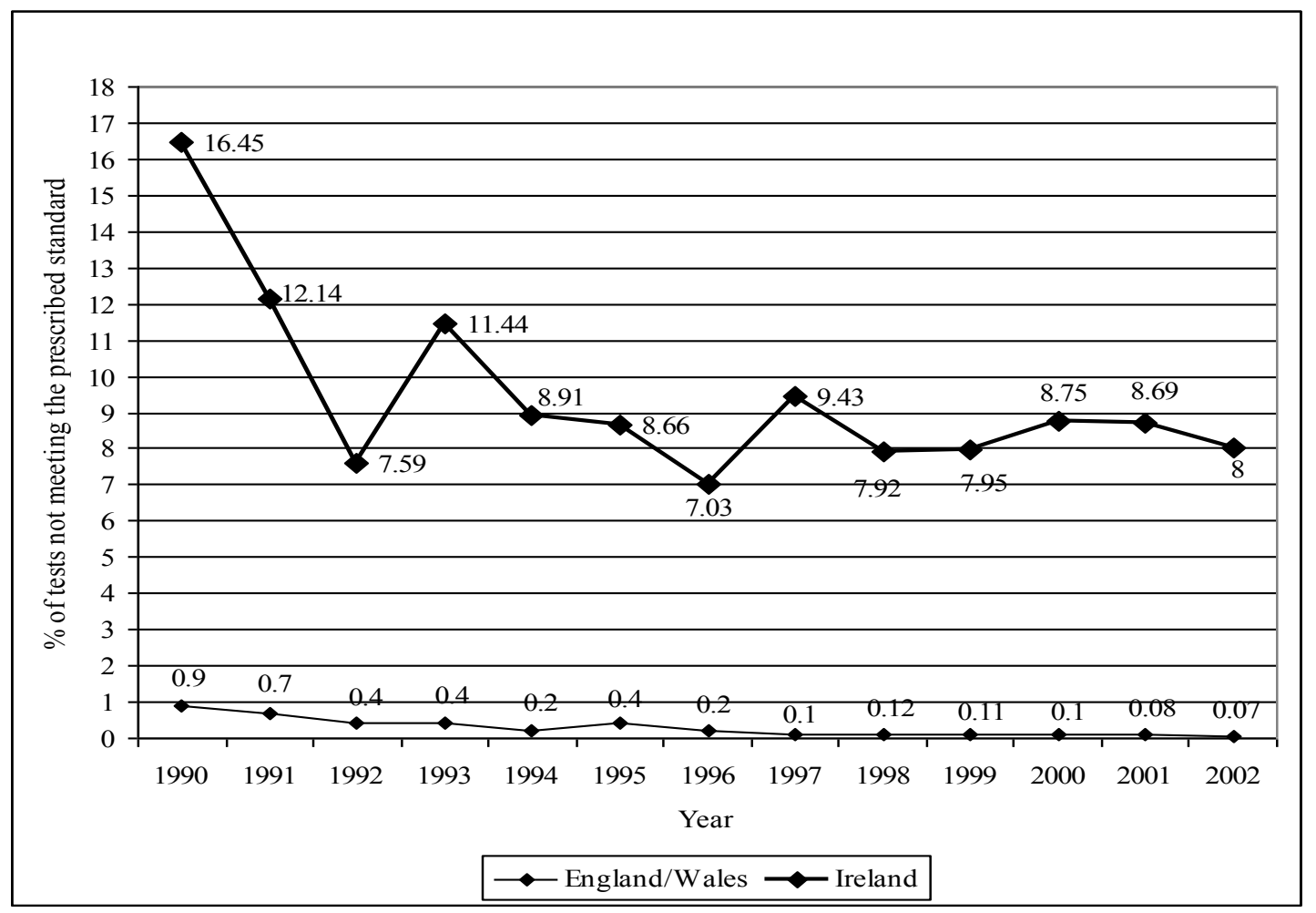

(Source: DWI, 1991-2003; EPA, 1991-2003)

Figure 5. Drinking water quality in England/Wales and Ireland in relation to iron, 1990-2002

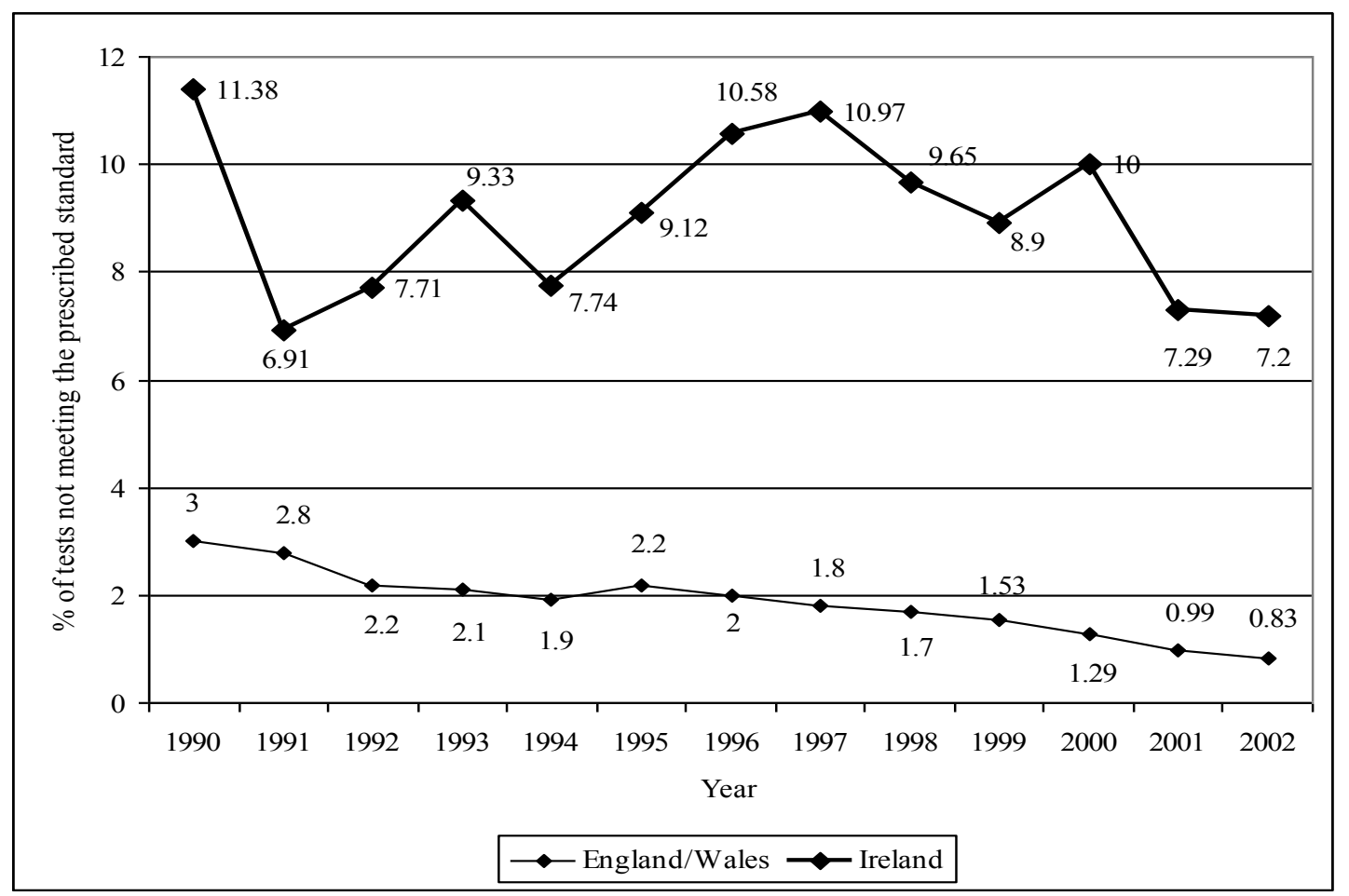

(Source: DWI, 1991-2003; EPA, 1991-2003) 
As noted previously, Figure 1 reveals clearly that Ireland has achieved a consistently lower overall compliance rating for drinking water quality, when compared to England/Wales. The annual drinking water reports, and the action plans for rural drinking water in Ireland, highlight that the overall quality of drinking water is lowered due to the poorer quality of water produced by group water schemes. In the context of Ireland, group water schemes refer to drinking water distributed by privately owned schemes that source and distributes their own supplies of drinking water (NFGWS, 2003). According to the Irish Environmental Protection Agency (EPA), group water schemes supply water of a lower quality because of contamination with animal and human waste and a lack of chlorination (EPA, 1999).

Assessing the effect of group water schemes on the overall quality of drinking water in Ireland has proved difficult, as annual reports have not always broken down quality data by group and public water schemes. As Figure 6 illustrates, the data available only allows assessment of overall quality supplied in relation to group and public water schemes back to 2000. What is notable is that drinking water from both group and public water supplies in Ireland is of a lower quality than in England/Wales (see Figure 6), suggesting that while group water schemes have had a negative impact on the overall result for drinking water quality in Ireland, their presence does not account for differences across the two national contexts.

Figure 6. Overall drinking water compliance in relation to public and group water schemes in Ireland, 2000-2002

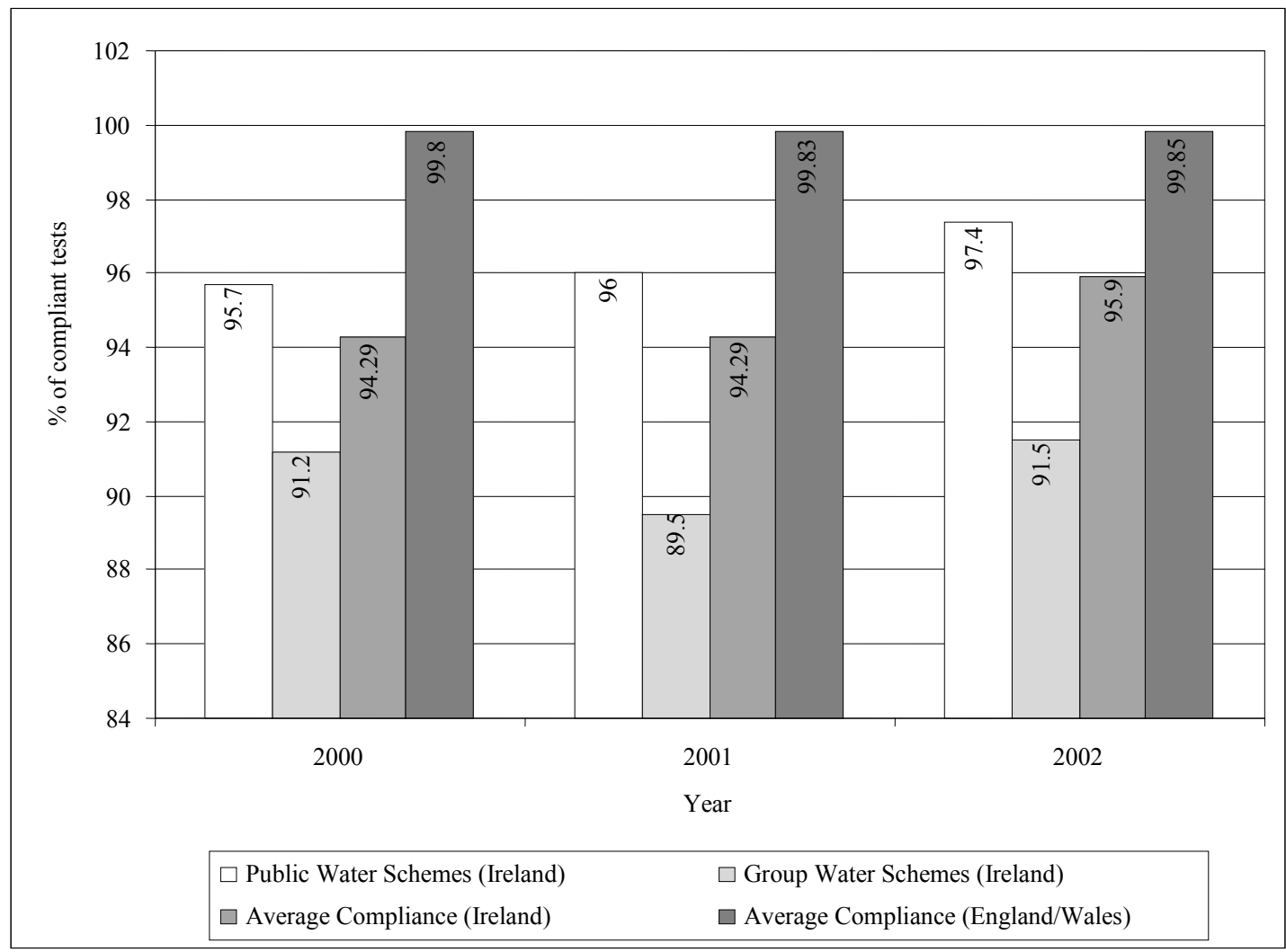

(Source: DWI, 2001-2003; EPA, 2001-2003) 


\section{ORGANISATIONAL ARRANGEMENTS}

To enable the organisational arrangements of England/Wales and Ireland to be established and discussed, the following discussion is split in two. The first section covers the organisational arrangements in Ireland to water services with the second section detailing the organisational arrangements in England/Wales from 1973 to 2002.

\section{Drinking water provision in Ireland}

Between 1973 and 2002, drinking water provision in Ireland was the responsibility of 88 local authorities ${ }^{5}$ and a growing number of group water schemes (European Communities [Quality of Water Intended for Human Consumption] Regulations, 1988). The delivery of water services is currently the responsibility of 88 local authorities, which supply approximately $90 \%$ of the population, and approximately 5,500 group water schemes, which supply approximately $10 \%$ of the population (EPA, 2003; EPA, 2005; Oasis, 2006; Scannell, 1995; 2005). Despite their 'independence', the group water schemes are under the statutory management of the local authorities who are responsible for monitoring and enforcing the quality standards contained within the Directive. Local authorities are then overseen by the Irish Department of the Environment (DOELG), who are responsible for Directive 80/778/EEC (Scannell, 1976; 1982; Quinn, 1992; Coyle, 1994; McGowan, 1999; OECD 2000; Taylor, 2001; NFGWS, 2003; 2004).

Following the 1988 European Communities (Quality of Water Intended for Human Consumption) Regulations, the Environmental Research Unit of the Irish environment department began to produce an annual, publicly available, report on drinking water quality. Prior to 1988, the enforcement of drinking water quality regulations rested with the local authorities themselves (Coyle, 1994; Scanell, 1995; Taylor, 2001). In 1993, this responsibility passed to the Environmental Protection Agency (EPA) (EPA Act 1992). In addition to monitoring and reporting on the quality of drinking water, the EPA is also responsible for monitoring and reporting on the quality of the wider water environment, and enforcing regulations with regard to waste and air pollution. The EPA is reliant upon water providers for data on the quality of drinking water (EPA, 2003b).

Between 1973 and 2002, the funding of water services underwent a series of notable changes in Ireland. Prior to 1978, water services provided by local authorities were funded via a mix of central government grants and revenue generated by domestic rates, which included a charge for water services (Ridge, 1992; Collins and Cradden, 1993). In relation to private group water schemes, users pay a subsidised rate for the services that are provided, with local authorities subsidising such schemes with the aid of central government grants (Collins and Cradden, 1993). However, domestic rates for water services, and thus the contribution of domestic users to the cost of water services in urban areas, were abolished ${ }^{6}$ in 1978 . To replace the loss in revenue, central government allocated an increased grant to local authorities in the form of a domestic rate grant (Ridge, 1992; Collins and Cradden, 1993). However, in 19821983 central government stopped making up this financial shortfall by decoupling the domestic rate grant from the locally determined domestic rates. This situation allowed

\footnotetext{
${ }^{5}$ Also known as public water scheme providers.

${ }^{6}$ County councils in rural areas retained the right to charge for domestic water supplies until 1997.
} 
the Treasury increasingly to determine what was spent at the local level (see Ridge, 1992).

In 1982, an Irish government circular enabled local authorities once again to charge for water services (Ridge, 1992; Collins and Cradden, 1993). In the context of a national fiscal crisis, the central government announced a decrease of eight per cent in the central grant levels to local authorities. Yet local authorities were allowed to mitigate the effects of this decrease somewhat by levying specific charges for the services they provided, such as water; although the national government did restrict the amount that local authorities could spend on local services, so as to manage the national fiscal crisis. As a consequence, expenditure on water services fell (see Ridge, 1992; Taylor, 1998, 2001). This decrease occurred because the national government sought to bring about economic stability by reducing inflation via a reduction in expenditure on public services (see Collins and Cradden, 1993; Coakley and Gallagher, 1999).

In response to their newly acquired revenue raising authority, by 1996 all but two local councils in Ireland (Dublin and Limerick) had developed some form of charging for water services, via the development and specification of an actual charge for water services in the annual rates bills sent to domestic householders (Collins and Cradden 1997). Despite the calculation and specification of charges for water services, in 1997 domestic user charges were once again discontinued, even though the direct billing and metering of business users has become increasingly commonplace (OECD, 2000; DOELG, 2004). Serving to complicate the funding of water services in Ireland further, group water schemes that are supplied with drinking water by local authorities also had their service charges abolished in 1997. However, users of private group water schemes still have to pay, albeit they are subsided by the relevant local authority. As consequence of the above changes, the DOELG has become responsible for financing the provision of water services via revenue generated from income tax. For the period 1994 to 1999, EU cohesion and structural funding also contributed to the funding of water services in Ireland, with this funding substantially decreasing between 2000 and 2006. This decrease occurred because of Ireland's improving financial situation relative to the rest of the EU (DOELG, 2002; 2004; Oasis, 2006).

\section{Drinking water provision in England/Wales}

For the period 1973 to 1988, water services in England/Wales were delegated to Regional Water Authorities (RWAs) and Statutory Water Companies.7 The RWAs were responsible for the delivery and regulation of sewerage and drinking water services. They were created as a result of the 1973 Water Act (Severn Trent Water Authority, 1980; Hassan, 1996; Summerton, 1998, Richardson, 2002), which brought about a marked rationalisation and regionalisation of water services in England/Wales (Parker and Sewell, 1988; Hassan, 1996). Prior to 1973, 157 water undertakings, 29 river authorities and 1,398 sanitary authorities existed in England/Wales. As a consequence of the 1973 Water Act, the responsibilities and functions of these various bodies were transferred to just 10 RWAs (Parker and Sewell, 1988; Hassan, 1996).

\footnotetext{
7 The term statutory water company refers to companies that were established via a UK Act of Parliament to provide drinking water only.
} 
This rationalisation shifted control of water resources away from the above authorities to large multi-regional service and regulatory management bodies (Hassan, 1996; Summerton, 1998). These RWAs took the form of nationalised industries in an organisational and constitutional sense. For instance, they were managed by a board appointed jointly by Ministers and local authorities (Summerton, 1998). Although each authority was legally distinct from central government and could determine their own spending priorities, Ministers were able to 'constrain' the actions of RWAs via the issuing of general and special directions, and the imposition of cash limits on new capital investment (Summerton, 1998). According to Saunders (1985), further government attempts to improve the efficiency of RWAs were driven by a belief that greater central bureaucratic control of public services was best able to help Britain respond to a period of economic decline and readjustment.

In 1989, the delivery of water services in England/Wales underwent major reform, passing entirely into the hands of the private sector as a consequence of the 1989 Water Act. The ten RWAs, created as a result of the 1973 Water Act, were floated on the London Stock Exchange (OECD, 1994, van den Berg, 1997; Richardson, 2002). In addition, 29 statutory water supply-only companies were allowed to float themselves on the stock market, if they so desired. As a consequence, a series of water company mergers took place, resulting in 19 statutory water companies by 1996 (OECD, 1994; Richardson, 2002)8. Currently, the privatised water industry is responsible for supplying approximately $99 \%$ of all drinking water in England/Wales (DWI, 2003)9.

In England/Wales, Section 60 of the 1989 Water Act empowered Secretaries of State for the Environment to appoint technical assessors to act on their behalf in the assessment and regulation of drinking water quality. Prior to this Act, the DoE was itself responsible for monitoring the quality of drinking water at the national level. This was done through sampling data supplied to it by the providers of water services, who were also responsible for the enforcement of drinking water quality standards. As a consequence of the 1989 Water Act, the Drinking Water Inspectorate (DWI) was established and charged with the task of monitoring and reporting on the safety of drinking water (DWI, 2004: 1).

Between 1970 and 1988, water services in England/Wales were funded via a changing mixture of charging of water users in relation to the rateable property value, RWA cross subsidisation, and funding from the Treasury (Parker and Sewell, 1988; WAA, 1988; Summerton, 1998). Following the reorganisation of the water industry by the 1973 Water Act, the Rate Support Grant from central government was removed. This meant that, for the first time, consumers began to pay more realistic water supply costs, albeit varying slightly due to the historic debts the RWAs had inherited (Parker and Sewell, 1988). Domestic customers were charged for water services according to the 'rateable value' of their properties, which continues to this day, with water charging still loosely related to rateable value (Parker and Sewell, 1988). Central to

\footnotetext{
${ }^{8}$ The duties of the water service companies and the water only companies are the same with regards to drinking water (Water Act [England], 1989).

${ }^{9}$ Approximately $1 \%$ of the population in England/Wales has its water needs met via private water supplies. The source of such supplies can include water drawn from a well, borehole, spring, stream, river, lake or pond (DWI, 2000).
} 
this funding arrangement is the ability of government to control expenditure and borrowing within the water industry, with both subject to the external finance limits:

'(the) external finance limit (EFL) is the amount the authority can raise from external sources. The overall limit for the industry is allocated as part of the Governments public sector borrowing requirement' (WAA, 1988: 27)

In England/Wales, as a consequence of privatisation, the Government no longer considers the financing of the water industry to be part of the public sector borrowing requirement (Hassan, 1995; Bakker, 2005). This has paved the way for the application of 'direct cost' recovery with regard to the delivery of water services ${ }^{10}$. To oversee the effective application and functioning of economic principles in a monopoly dominated market place, and in similarity with previous network utility privatisations, government established the Office of Water Services (Ofwat) was in 1989 to act as an economic regulator (Bakker, 2001; Ofwat 2004).

\section{DISCUSSION AND CONCLUSIONS}

To enable the findings of this study to be summarised and appropriate conclusions drawn about drinking water quality and associated organisational arrangements in England/Wales and Ireland, this section has been split in two. The first section summarises the study's finding with regard to water quality. The second section discusses the key organisational differences in relation to the provision of drinking water and its regulation.

Drinking water quality. This paper has established that the quality of drinking water in England/Wales and Ireland to have been a problem of growing concern in the 1970s and 1980s. In England/Wales, available historical data indicates the role of government-sponsored research in helping establish the extent of drinking water quality problems. However, in Ireland there was little public reporting and concern over the quality of drinking water. From the data identified, major problems relating to drinking water revolved around contamination by lead and nitrate, particularly in England/Wales. In Ireland, this issue was particularly poorly documented. While reports highlighted a growing risk of contamination by nitrate, there were no specific reports on the contamination of drinking water, as occurred in England/Wales.

Between 1990 and 2002, the drinking water quality data contained in the annual national monitoring reports for England/Wales and Ireland demonstrates England/Wales to have obtained a higher overall level of compliance with standards laid down by Directive 80/778/EEC. The data also served to show that England/Wales have managed to bring about far more significant improvements in drinking water quality with regards to particular parameters. Within Ireland, group water schemes have been found to have a significant impact on the overall quality of drinking water nationally, as their compliance record is poorer than that for public schemes. However, it is of note that these water schemes do not account sufficiently for Ireland's lower overall compliance rating and higher compliance failures with

\footnotetext{
${ }^{10}$ Direct, within the context of this thesis, serves to imply that consumers of drinking water are directly billed for the full cost of the volume of water services they consume.
} 
'problem parameters'. Both public and group water schemes demonstrate higher failure rates in comparison with England/Wales.

Organisational arrangements. The provision of drinking water in England/Wales and Ireland diverges in three broad areas; namely, with regard to the role of government in provision; the role of government in finance; and the role of government in regulation. The role of national level government has been chosen to highlight differing organisational arrangements as they are ultimately responsible for ensuring compliance with European water quality standards. In particular, national governments, not the providers of water services, are subject to non-compliance proceedings by the European Commission. Consequently, they provide a suitable focal point for highlighting differences as they have to develop organisational arrangements to ensure the quality standards of Directive 80/778/EEC are met.

Firstly, they differ with regard to the role government has come to play in the provision of drinking water. In Ireland, the national government has remained responsible for the delivery of drinking water via local authorities (in the main), and, to a not insignificant extent, through group water schemes. In contrast, since 1989, drinking water supply has been the responsibility of the private sector in England/Wales. This aside, the provision of drinking water in Ireland is significantly more fragmented than in England/Wales. So, while only 29 companies are responsible for the provision of drinking water to a population of some 60 million in England/Wales, in Ireland drinking water is supplied to a population of just 3.9 million by some 88 local authorities and approximately 5,500 group water schemes. Industry and government officials in Ireland note that the organisational fragmentation of drinking water caused by group water schemes has hindered achievement of the Directive's quality standards. This is due to the operators of such schemes lacking an awareness of current treatment techniques and to the limited funds government was able and willing to allocate to tackling problems of non-compliance by such schemes. Arguably, the heightened level of organisational fragmentation is also serving to prevent economies of scale being achieved with regard to the dissemination and sharing of technical and financial resources, which is crucial to the achievement of the Directive's standards. Indeed, it might very well be the case that such fragmentation is also serving to prevent the 'blending' of drinking water sources. This technique has, arguably, been made ever more possible by the high level of organisational rationalisation in England/Wales. This rationalisation has potentially allowed water companies to bring under their control and thus utilise a wider array of drinking water sources. As a result, they have been able to better meet the quality standards of Directive 80/778/EEC because they have been able to mix a wider array of drinking water sources to dilute potentially harmful substances to legally compliant levels.

The second key difference concerns the financing of drinking water supply by national government. Since 1989, water services in England/Wales have been subject to the principle of full cost recovery via application of the user pays principle for all users, meaning that the consumer pays the full costs associated with receiving services. By contrast, since 1997, the Irish state has stopped charging domestic consumers for water services. Ireland has instead preferred to finance the provision of water services via general taxation. Therefore, it can be argued that the actions of government in England/Wales have allowed the provision of water services, for 
example drinking water, to be treated more as a commodity in comparison to Ireland. In Ireland, the removal of domestic charges has prevented the commodification of domestic water services because such consumers do not pay for what they use or are perceived as using.

Water services in Ireland have been the recipient of substantial EU funding since the early 1990s. This contrasts markedly with the provision of water services in England/Wales, which have been entirely financed by the consumers of water services (overseen by Ofwat, a non-departmental, state sponsored economic regulator). Despite these differences in funding arrangements, both countries, since 1990, have witnessed increased investment in water services. Also, as highlighted by Figure 1, drinking water in England/Wales and Ireland has, since 1990, become increasingly compliant with the quality standards of the Directive. In both national contexts, when the water industry was under the ownership of national government during the 1970s and 1980s, public expenditure on water services decreased as a consequence of government limiting public expenditure. This was part of a wider government economic strategy to control inflation and restore economic stability. This had a detrimental impact upon the ability of water providers to meet the quality standards of Directive 80/778/EEC. Awareness of such government actions is useful in helping to explain why the water industry in England/Wales and Ireland did not appear to take more pride in producing and providing cleaner drinking water, even when they knew problems existed. While this finding appears to suggest that drinking water quality is directly related to funding levels, the author acknowledges that any such relationship is far from linear. Improvements in drinking water quality are also dependent upon a series of others factors, such as regulatory arrangements, as this paper has shown. However, it is notable that many interviewees and senior water practitioners have commented on the role played by adequate levels of finance in helping the water industry to effectively meet its regulatory obligations, none more so than the quality standards laid down by Directive 80/778/EEC (see Summerton, 1998; Richardson, 2002; Jenkins, in press).

The final key difference is related to the role played by national government in enforcing the Directive's standards. Since 1989 the enforcement of the Directive's standards in England/Wales has been the principal responsibility of the Drinking Water Inspectorate (DWI), a state sponsored regulatory agency. Lagging some four years behind England/Wales, the Irish Government established the EPA with the task of monitoring the quality of drinking water. Both these agencies produce annual reports on drinking water quality based upon sample data supplied by the providers of water services. Arguably, this interdependency is a weakness as it allows for the possibility of misreporting in an attempt to avoid the unwanted attention of the regulator. While, to the knowledge of the author, this situation has not occurred, it is notable that in the early days of privatisation water companies in England/Wales were criticised for failing to submit drinking water quality data to the regulator (see DWI, 1990, 1991). Indeed, some of the water providers in Ireland have also been criticised on similar grounds (see EPA, 1990, 1991). While it seems inconceivable that the providers of drinking water would seek to the put the health of the public at risk by misreporting drinking water quality data, it is notable that water companies in England/Wales have been fined for misreporting consumer complaints and have subsequently been fined for doing so. Therefore, an independent monitoring agency, capable of directly monitoring drinking water quality via its own sampling regime, 
would appear to be a more progressive and robust organisational approach to ensuring the supply of safe high quality drinking water. The extent to which any such body should be created at the European level is largely a matter of politics, but independent drinking water regulatory organisations should be viewed as a step in right direction in helping to improve the implementation of current and future European drinking water directives.

In England/Wales, the DWI is responsible for regulating the compliance of privately owned water providers with the standards of the Directive, whereas in Ireland the EPA is responsible for regulating compliance by government-owned and funded providers of water services, notably local authorities. In relation to any effect this has had on the impetus to achieve the quality standards of the Directive, the DWI in England/Wales has been found to have brought legal proceedings against water providers if they fail to meet the quality standards of the Directive. For example, in January 2002, Yorkshire Water was fined a total of $£ 23,261$ following legal proceedings brought by the DWI for failing to supply water fit for human consumption (DWI, 2002b). Such prosecutions aim to encourage the providers of drinking water in England/Wales to meet the quality standards of the Directive. In contrast, the EPA in Ireland has not prosecuted local authorities for failing to achieve the quality standards of the Directive. This reluctance has been found to be associated with water providers in Ireland making significantly weaker progress in meeting the quality standards of the Directive. When EPA employees were asked why the EPA had not brought any legal proceedings against local authorities who breached the Directive's standards, they argued that such enforcement action was not conducive to maintaining a good working relationship with local authorities. In effect, the EPA was unlikely to prosecute because such action would result in one section of government publicly criticising another, which was to be avoided. As to what extent this appears to be indicative of the Irish government ultimately sanctioning the breaching of the Directive's standards is largely a matter of public and party politics. As forthcoming research by the author has found (see Jenkins, in press), a political will for change has to exist, without such 'will' the political priority accorded drinking water quality will remain low in comparison with other issues, such as stimulating economic growth and balancing the public finances. Therefore, the above situation draws attention to a fundamental difference in the regulatory approach to how the standards of the Directive are enforced. In particular, the willingness of the DWI, in England/Wales, to bring legal proceedings to enforce the standards of the Directive is indicative of a more fixed and legal approach to the regulation of drinking water, that is in turn more removed from the political priorities of national government. Whereas in Ireland, the approach of the EPA towards regulatory enforcement appears to be more flexible and less legalistic, due to the unwillingness of the EPA to take enforcement actions against the providers of drinking water, with this due to government involvement in all stages of water supply and its regulation.

In conclusion, and with regard to the future provision of drinking water, it is suggested that where countries are failing to bring about improvements in drinking water quality, they should seek to reduce the number of organisations involved in the provision of drinking water. This response should help to ensure better quality control as it will help create larger organisations that should be better able to more readily achieve economies of scale that enable technical and financial solutions to be more readily embraced. This paper has clearly shown that markedly rationalised 
organisational arrangements appear to be associated with higher and more consistent levels of drinking water quality. It is of note that the markedly rationalised system of England/Wales has been accompanied by a regulatory system that is more legalistic and dependent on the private sector, with the willingness to prosecute being associated with an ability to more effectively tackle drinking water quality problems. Therefore, any such organisational rationalisation should also be accompanied by a more legalistic system of enforcement. The findings of this paper should not be ignored by national governments and their regulatory agencies. While the approach of England/Wales appears to have had a positive impact on the quality of drinking water, the author duly acknowledges that other so called 'steering tools' like; bench marking, naming and shaming, or indeed complimenting the providers of drinking water, have their role to play in creating effective organisations that are capable of delivering safe high quality drinking water.

\section{REFERENCES}

Arksey, H., Knight, P. 1999. Interviewing for Social Scientists. Sage Publications: London.

Atkinson, J. W. 1978. British Experiences on Problems of Drinking Water Quality. In: Russel, C. (Ed), Safe Drinking Water: Current and Future Problems - Proceedings of a National Conference in Washington D.C.

Bakker, K. 2005. Neoliberalizing Nature? Market Environmentalism in Water Supply in England and Wales. Annals of the Association of American Geographers 95 (3), 542-565.

Bakker, K. 2001. Paying for water: water pricing and equity in England and Wales. Transactions of the Institute of British Geographers 26, 143-164.

Baxter, J. and Eyles, J. 1997. Evaluating qualitative research in social geography: establishing 'rigour' in interview analysis. Transactions of the Institute of British Geographers 22, 505-525.

Blaikie, N. 1991. A critique of the use of triangulation in social research. Quality and Quantit, 25, 115-36.

Breach, R. A. 1989. The EC Directive on Drinking Water (EEC 80/778). Journal of the Institute of Water and Environmental Management 3, 323-327.

Collins, K., 1988. Report on the Implementation of European Community Legislation Relating to Water (European Parliament Session Document A2 0298/80). European Parliament: Brussels.

Collins, N. and Cradden, T. 1993, \& 1997. Irish Politics Today. Manchester University Press: Manchester. 
Commission of the EC. 1980. Council Directive 80/778/EEC relating to the quality of water intended for human consumption. Official Journal of the European Communities (L229), 30 ${ }^{\text {th }}$ August. EC: Brussels.

Commission of the EC. 1992. European Community Environment Legislation. Volume 7 Water. European Commission. Brussels.

Coyle, C. 1994. Administrative Capacity and the Implementation of EU Environmental Policy in Ireland. In: Baker,S., Mitlon, K., and Yearly, S. Protecting the Periphery: Environmental Policy in the Peripheral Regions of the European Union. Cass: Ilford.

Coakley, J., and Gallagher, M. 1999. In: Coakley, J., and Gallagher, M. Politics in the Republic of Ireland: Routledge: London.

Dáil Debates, 1983. Volume 346, 22-11.83.

Dáil Debates, 1989. Volume 392, 02-11-89.

Daly, D., and Daly, E. P. 1984. A Review of Nitrate in Groundwater and the Situation in Ireland. Irish Journal of Environmental Science 3 (1), 1-13.

Department for the Environment, 1977. Lead in Drinking Water Survey, 1975 1976. Pollution Paper No. 12. HMSO: London.

Department of the Environment and Local Government. 1988. Circular L8/88. European Communities (Quality of Water Intended for Human Consumption) Regulations. DOELG: Dublin.

Department of the Environment and Local Government. 2002. Water Services Investment Programme 2003-2005. DOELG: Dublin.

Department of the Environment and Local Government. 2004. What We Do Water Services:

http://www.environ.ie/DOEI/DOEIPol.nsf/wvNavView/wwdWaterServices?Op enDocument\&Lang=en - accessed $-12 / 05 / 2004$.

Denzin, N. 1989. The Research Act in Sociology: A theoretical introduction to Sociological Methods. Butterworths: London.

Drinking Water Inspectorate. 1990, 1991, 1992, 1993, 1994, 1995, 1996, 1997, 1998, 1999, 2000, 2001, 2002a, 2003. Drinking Water: A Report by the Chief Inspector, Drinking Water Inspectorate. HMSO: London.

Drinking Water Inspectorate. 2002b. Press Notice: Yorkshire Water Pleads Guilty to Charges of Supplying Water Unfit for Human Consumption. DWI: London.

Drinking Water Inspectorate. 2004. Who are the Drinking Water Inspectorate?: http://www.dwi.gov.uk/consumer/faq/dwi1.htm - accessed - 19/04/2004. 
Environmental Protection Agency. 1990, 1991, 1992, 1993, 1994, 1995, 1996, 1997, 1998, 1999, 2000, 2001, 2002, 2003, 2005. The Quality of Drinking Water in Ireland. Environmental Protection Agency: Co. Wexford.

Environmental Protection Agency Act (Ireland). 1992. DOELG: Dublin.

Environmental Protection Agency. 2003b. Drinking Water. Available at: http://www.epa.ie/OurEnvironment/Water/DrinkingWater/. Accessed $14 / 03 / 04$

Flanagan, P. J., and Toner, P. F. 1972. The National Survey of Irish Rivers: A Report on Water Quality. Water Resources Division: Dublin

Flick, U. 2002. An Introduction to Qualitative Research. Sage Publications: London.

Gouldson, A. and Murphy, J. 1998. Regulatory Realities: The Implementation and Impact of Industrial Environmental Regulation. Earthscan: London.

Guba, E. 1978. Toward a Methodology of Naturalistic Inquiry in Educational Evaluation. Unibersity of California: Los Angeles.

Hoggart, K., Lees, L. and Davies, A. 2002. Researching Human Geography. Arnold: London.

Hassan, J. 1995. The Impact of EU Environmental Policy on Water Industry Reform. European Environment 5, 45-51.

Hassan, J. 1996. The European water environment in a period of transformation. Manchester University Press: Manchester.

Hodder, I. 2000. The Interpretation of Documents and Material Culture. In: Denzin, N. and Lincoln, Y. Handbook of Qualitative Research. Sage: London.

House of Commons Debates, 1985. Volume 84, 21-1-85, Col 551

IIRS, 1975. Recommendations for septic tank drainage systems suitable for single houses. Institute for Industrial Research and Standards. SR. 6.

Jeffery, J. 1992. Privatised Water - Organisation, Regulation and Funding. Transcript of speech given at the International Water Services Association Confernece in Malaysia.

Jenkins, J. O. In press. The impact of politics on the application of the Drinking Water Directive (80/778/EEC). Water and Environment Journal

Jick, T. 1983. Mixing qualitative and quantitative methods: triangulation in action. In: van Maanen, J. (Ed), Qualitative Methodology. Sage Publications: London. 
Kramer, L. 2000, \& 2003. EC Environmental Law. Sweet \& Maxwell: London.

Lincoln, Y. and Guba, E. 1985. Naturalistic Inquiry. Sage: London.

Lowe, P. and Ward, S. 1998. British Environmental Policy and Europe: Politics and Policy in Transition. Routledge: London.

Mason, J. 1998. Qualitative Researching. Sage Publications: London.

McGowan, L. 1999. Environmental Policy. In: Collins, N. (Ed), Political issues in Ireland today. Manchester University Press. Manchester.

Minichiello, V., Aroni, R., Alexander, L. and Timewell, E. 1995. In-Depth Interviewing: Principles, Techniques, Analysis. Pearson Education: Sydney.

National Federation of Group Water Schemes. 2003. Action Plan for Rural Water Quality. Monaghan

Nicolson, N. 1993. An Introduction to Drinking Water Quality (IWEM Booklet 3). IWEM: London.

Oasis. 2006. Water Charges in Ireland. Available at: http://oasis.gov.ie/utilities. Accessed - 07/02/2006.

O’Donnel, C. 1980. Organic Micropollutants in Irish Waters: Results of a Pilot Study. Division of Water Services: Dublin.

Office of Water Services. 2004. Protecting the interests of water consumers: An introduction to Ofwat. Available at:

http://www.ofwat.gov.uk/aptrix/ofwat/publish.nsf/Content/general_leaflet20104 Accessed - 19/04/2004.

Organisation for Economic Co-operation and Development. 1994. Environmental Performance Reviews - United Kingdom. OECD: Paris.

Organisation for Economic Co-operation and Development. 2000. Environmental Performance Reviews - Ireland. OECD: Paris.

Parker, D. and Sewell, D. 1988. Evolving Water Institutions in England and Wales: An Assessment of Two Decades of Experience. Natural Resources Journal 28, 751-785.

Patton, M. 2002. Qualitative Evaluation and Research Methods. Sage Publications: London.

Pearce, F. 1982. Watershed: The Water Crisis in Britain. Junction Books: London.

Richardson, H. 2002. The Water Industry in England and Wales. Specialist Group on Management and Institutional Affairs Newsletter, August: 11-19. 
Ridge, M. 1992. Local Government Finance and Equalisation: The Case of Ireland. Fiscal Studies 13 (3), 54-73.

Rubin, H. Rubin, I. 1995. Qualitative Interviewing: The Art of Hearing Data. Sage Publications: London.

Quinn, J. 1992. Water Quality Management: Policy and Practice in Selected Countries. American Petroleum Institute: Washington.

Scannell, Y. 1976, 1982, 1995, 1996, 2005. Environmental and Planning Law in Ireland. Round Hall Press: Blackrock.

Seldon, A. 1986. Contemporary History: Practice and Method. Blackwell: Oxford.

Semple, A. 1993. The Implications of the EC Legislation and the Future of Water Quality Obligations. Journal of the Institution of Water Officers 30 (2), 14-17.

Semple, A. 2001. Water Services in the United Kingdom. Transcript of speech given at ENGREF University.

Severn Trent Water Authority. 1980. Water Quality 1979/80. Severn Trent Water Authority: Birmingham.

Summerton, N. 1998. The British Way in Water. Water Policy 1, 45-65.

Taylor, G. 1998. State Regulation and The Politics of Public Service: The Case of the Water Industry. Mansell: London.

Taylor, G. 2001. Conserving the Emerald Tiger. Arlen House: Galway. National Federation of Group Water Schemes. 2004. Background:

http://nfgws.ie/background.htm - accessed - 07/05/2004

Taylor, G. and Horan. A. 2001. From cats, dogs, parks and playgrounds to IPC licensing: policy learning and the evolution of environmental policy in Ireland. British Journal of Politics and International Relations 3 (3), 369-392.

Toner, P. and Lenox, L. 1980. Nitrate Content in Irish River Waters. Water Resources Division: Dublin.

van den Berg, C. 1997. Water Privatisation and Regulation in England and Wales. Public Policy for the Private Sector 115. The World Bank Group.

Water Authorities Association. 1988. WaterFacts 1988. WAA: London.

Water Resources Division, 1986. A Review of Water Pollution in Ireland. Water Resources Division: Dublin. 
Weale, A., Pridham, G., Cini, M., Konstadakopulos, D., Porter, M. and Flynn, B. 2000. Environmental Governance in Europe: An Ever Closer Ecological Union? Oxford University Press: London. 